\title{
MAINSTREAMING SUSTAINABLE DEVELOPMENT GOALS IN GHANA'S ENERGY SECTOR WITHIN THE FRAMEWORK OF PUBLIC- PRIVATE PARTNERSHIPS: CHALLENGES, OPPORTUNITIES AND STRATEGIES
}

\author{
Owusu-Manu1 ${ }^{1}$, D., Adjei², T.K., Mensah-Sackey ${ }^{3}$, D., Edwards ${ }^{4}$, D.J., Hosseini ${ }^{5}$, M. Reza, \\ ${ }^{1}$ Department of Construction Technology and Management, \\ College of Art and Built Environment, \\ Kwame Nkrumah University of Science and Technology, Ghana \\ Email: d.owusumanu@gmail.com \\ ${ }^{2,3}$ Department of Mechanical Engineering, \\ Institute of Distance Learning, \\ Kwame Nkrumah University of Science and Technology, Ghana \\ E-mail: davidsackey.co.uk@gmail.com; kankamthomas@gmail.com \\ ${ }^{4}$ Faculty of Technology Environment and Engineering \\ Birmingham City University, United Kingdom \\ Email: david.edwards@bcu.ac.uk \\ ${ }^{5}$ School of Architecture and Built Environment, \\ Deakin University, Geelong, Australia \\ Email: reza.hosseini@deakin.edu.au; igor@deakin.edu.au
}

\begin{abstract}
Purpose- This paper is anchored in a premise of a universal call to action by all United Nations member states in 2015 to end poverty, protect the planet and ensure that all people enjoy peace and prosperity by 2030 within the blueprint of the sustainable development goals. the purpose of this research is to explore exploration of challenges, opportunities and strategies for mainstreaming sustainable development goals in Ghana's energy sector within the framework of public-private partnerships

Design/methodology/approach- Literature review was carried out to explore concepts, theories, and frameworks for initiating Public-Private-Partnerships. Best local and international practices in the implementation of PPP projects; challenges and opportunities in the implementation of PPP projects, strategies for mainstreaming the sustainable development goals in Ghana's energy sector, and assess business action in the implementation of the sustainable development goals in Ghana's energy sector. The study is situated within the social constructionist philosophical tradition. The qualitative research strategy was adopted as the main methodological choice. Interview guides were used to collect data from respondents in the Accra metropolis. Eighteen (18) questionnaires were distributed and ten (10) retrieved out of the number representing a response rate of 56 percent. A thematic analysis technique was adopted to analyze the data.
\end{abstract}


Findings- The lack of a PPP policy and law in Ghana, issues of conflict of interest in PPP projects, excessive government control over projects, cumbersome licensing and legal regime, and the general economic stability of the country were the most significant challenges identified to PPPs. However, opportunities identified were technology transfer, efficiency gains, and mobilization of additional resources for development on the government side whereas the opportunities for the private sector lie in creating new niches for themselves, becoming market leaders, and enhancing their brand reputation as well as profits. Awareness creation and education for companies, making business models inclusive, linking CSR with SDGs, exploring business opportunities in SDGs such as carbon trading, etc., aligning national policies with SDGs, establishing a sustainability unit in energy companies and forming effective partnerships with relevant bodies were the strategies proposed for mainstreaming the SDGs in Ghana's energy sector.

Research limitation- It was established from this study that indeed PPPs have a major role to play in unleashing all available forces and prospects towards achieving the SDGs. The findings of this research will serve as a guide to policymakers, the private sector, and development partners helping them identify the most effective strategies and avenues for implementing the SDGs especially in the context of the energy sector. This paper is constrained to the energy industry in Ghana. It provides a theory-based direction on how companies in the energy sector can contribute to social and economic interventions through a framework of PPP framework within the SGDs. Future research may explore how companies in other sectors may contribute to the sustainability discourse.

Practical Implication- This will ultimately lead to additional funding to support government efforts in the implementation of SDGs, honing of sustainable (inclusive) business models, creating an enabling environment for PPPs towards inclusive growth and national development leaving no one behind. It recommended that there should be a national policy and law on PPPs and the private sector should be incentivized to engage government in PPPs implementation for the SDGs. Theoretically, this research contributes to the policy analysis discourse and scaling-up literature on the SDGs.

Originality/value- This research explores the challenges associated with mainstreaming the SGDs in the energy sector from a public-private business perspective. It also offers a new policy, economic, and legal regulatory framework that contributes to emerging trends. The outcome of the analyses advocates for clear business strategies for implementation of the SDG apart from corporate social responsibilities (CSR).

Keywords: Energy Sector, Public-Private, Policy, Mainstreaming, MDGs, SDGs, Sustainability. 


\section{INTRODUCTION}

During the last couple of decades, the public-private partnership (PPP) concept has gained ground globally mostly realized in developing countries (Kwofie et al., 2019; Osei-Kyei \& Chan, 2017) One key approach to achieving sustainable development is by the formation of partnerships and alliances between public and private institutions to synergize for a larger and inclusive impact on people and communities (Sánchez et al., 2020).

The private sector may contribute to national development under the following: job creation and employment, contribution to national income, delivery of critical goods and services, equity financing, tax revenues, efficient flow of capital for production diver's engagement in a form of social interventions through Corporate Social Responsibility (CSR) initiatives (BenshaulTolonen et al., 2019; Yakovleva et al., 2017). With the SDGs in place, businesses now have a much clearer set of long term universal priorities and alignment between policymakers, civil society, and the private sector (Pedersen, 2018).

In 2015, the United Nations and its member states adopted the Sustainable Development Goals (SDGs) as the successor to the Millennium Development Goals (Acuti et al., 2020; Pedersen, 2018) The seventeen (17) goals are to address issues on the environment, economy, and society (Kynčlová et al., 2020). These Goals are expected to be achieved by the year 2030 amidst the many existing challenges faced by developing countries (Castor et al., 2020; Chirambo, 2018). The enormity of the challenges calls for extra effort from governments and all stakeholders towards a change of mindset and attitude, resource mobilization, and setting the right policy environment for a paradigm (Kumi et al., 2020). The United Nations Conference on Trade and Development (UNCTAD) has estimated that about 5-7 trillion US Dollars will be required to achieve the SDGs globally (UNCTAD, 2014).

Arhin (2016) argued that in other to advance the 17 Sustainable Development Goal (SDGs), NGOs would play crucial roles in service provision, advocacy, and facilitation. The research further concluded that the recent changing progress in activities might affect the institutional capacity of numerous NGOs that are pursuing SDGs agenda. AlQattan et al., (2018) explored the potential of Waste-to-Energy (WTE) technologies for the SDGs and concluded that elevating waste-to-energy (WTE) technologies will support the comprehensive effort towards achieving the SDG numbers seven and eleven. According to Abubakari et al., (2018) Ghana is not prepared for the implementation of a long-term SDG plan even though it has one with an extensive focus into the future.

Similarly, Opoku et al., (2019) examined poverty alleviation among persons with disabilities via the SDGs in Ghana. They found out that the Government of Ghana (GOG) has not made enough effort to address the needs of poor persons with disabilities. In a research by Acheampong et al., (2019) on Ghana's readiness to attain the SDG number 7. They recommended that micro and small-scale biofuel initiatives be the focus in remote areas to offer alternative sources of energy 
Kumi et al., (2020) theorise that the private sector has the potential to support the realization of several of the SDGs. They suggested corporate social (CRS) responsivity initiatives from the private sector to help in this regard.

Recent years have seen discussions about the SDGs shifting development trends on sustainability across different countries. While the issues discussed focus mainly on other developed countries, there is still very limited empirical research in Ghana. To address this deficit, this paper, aim to explore the challenges, opportunities and strategies for mainstreaming sustainable development goals in Ghana's energy sector within the framework of public-private partnerships. In doing so, the paper was examined under three (3) objectives (i) to identify best practices in the implementation of publicprivate partnerships for adoption in Ghana (ii) to identify opportunities and challenges in the implementation of public-private partnerships in Ghana. (iii) to propose strategies for mainstreaming the sustainable development goals in Ghana's energy sector. The rest of the paper is structured as follows. Section 2 provides a literature review on PPP conceptualization in Ghana. Section 3 describes the conceptual framework. The methodology and data sources were discussed in section 4. Section 5 outlines the data analysis. Section 6 presents the outcomes, contributions, and implications. Finally, conclusions and remarks are offered in Section 7.

\section{CONCEPTION AND EVOLUTION OF PUBLIC PRIVATE PARTNERSHIPS IN GHANA}

Like many other developing countries, the Government of Ghana (GoG) has also demonstrated great interest in the PPP concept (Owusu-Manu et al., 2017). PPP is defined within the Ghanaian context as a contractual arrangement between a public entity and a private sector party with clear agreement on shared objectives for the provision of public infrastructure and services traditionally provided by the public sector (Badu et al., 2013; Painuly, 2009).

Badu et al., (2011) pointed out key features of Ghana's PPP. First, it is a contractual arrangement between a contracting authority (public entity) and a private consortium. The contracting authorities are mostly the metropolitan, municipal, and district assemblies (MMDAs), and ministries, departments, and agencies (MDAs). The private partner could be a developer or a multi-stakeholder consortium (Liang \& Hu, 2020). Additionally, it is worth noting that the private partner could also be either a nonprofit or a profit-oriented consortium as well (Han et al., 2020).

Second, the arrangement involves the sharing of responsibilities and risks (Jingning \& Wenkang, 2016; Taghizadeh-Hesary \& Yoshino, 2019)This feature implies that there should be a mutual agreement of objectives and responsibilities among parties. Traditionally, there are specific public infrastructure projects that are provided by the government such as transportation (railway, highways), public hospitals, housing, and many others (Owusu-Manu et al., 2019). These physical public infrastructures when adequately financed, constructed, and operated by the private sector could only be termed as PPP in Ghana (Badu et al., 2013).

In Ghana, the PPP ideology began since the early 1990s, the private sector has been actively involved with public service delivery since (Agarchand \& Laishram, 2017). However, the private 
sector's participation has mainly been the management of public service in the waste, energy, telecommunication, and sanitation sectors (Kwofie et al., 2019). Hitherto, physical public infrastructures such as roads, railways, power plants, airports, bridges, and public hospitals have private investors' participation been relatively low before the 1990s, but on a contrary, this is no more the case in recent times (Simshauser et al., 2016). It has, therefore, become necessary in recent times for the government to engage the private sector to assist in the delivery of more physical public infrastructures following the global financial crisis, which has limited the flow of donor funds (Liang \& $\mathrm{Hu}, 2020$ ).

There are many physical public projects which are currently at the preparation stages and are yet to go through the full procurement stage. The pace of PPP implementation in Ghana has been considerably slow, and more efforts from key stakeholders including the government, private investors, civil society groups, and academics are required (C. Ameyaw et al., 2015; OwusuManu et al., 2017, 2018). There has been conscious determination to increase the local private sector in through policy (Kwofie et al., 2016). According to (C. Ameyaw et al., 2015), since 2011 resources has been committed to develop the structures for effective implementation of PPP in Ghana. This has resulted in the drafting of PPP law, creation of PPP unit in the Ministry of Finance (MoF) and a Minister of State at the Presidency in charge of PPP.

Credence to the World Bank (WB), in its Private Participation in Infrastructure (PPI) database lists twenty-three (23) projects from 1990-2014 that have reach financial closure, of which eight (8) are independent power producer (IPP) as presented in Figure 1 below. On October 3, 2014 the largest IPP in Ghana reached its financial closure under an arrangement in which the Kpone Independent Power Plant (KIPP) project came to light. The project was set up as a special purpose vehicle (SPV) by CenPower Generation according to the World Bank. Furthermore, the WB report captured many different PPP projects that have come to fruition with others at various procurement stages. For example, the Teshie-Nungua water desalination project between Ghana Water Company Limited (GWCL) and Befesa Desalination Development Ghana Ltd, AccraTema, Accra-Kumasi, Accra-Takoradi roads, Tema port expansion project, the Boankra Inland Port and the Eastern Railway Line. While there is recognition that PPPs will play a significant role in delivering infrastructure projects, the legal framework to advance and implement PPPs in Ghana is at a nascent stage (Owusu-Manu et al., 2018). 


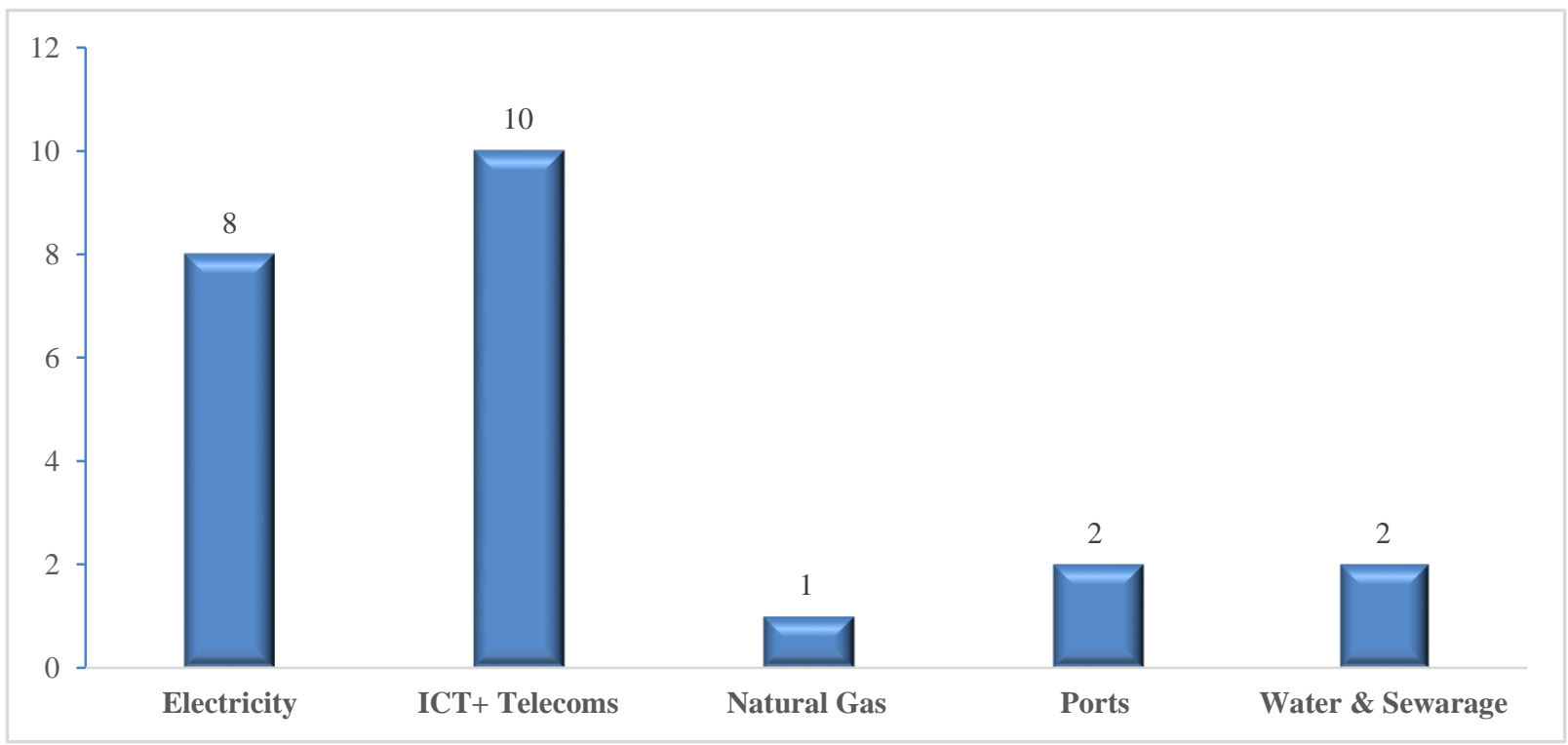

Categories of PPP projects in Ghana

Source; (The World Bank, 2017)

\section{CHALLENGES AND OPPORTUNITIES FOR PPP IMPLEMENTATION IN GHANA} According to Badu et al., (2011) and Owusu-Manu et al., (2019) major basic reasons for PPP in Ghana are that PPP promotes the quick delivery of public infrastructure projects; it reduces government financial burden; and lastly, it allows for shared risks. In Ghana, public projects procured through the traditional bid-build method are often delayed due to several reasons including the lack of public funds, improper planning, and design variations.

Furthermore, private investors also need to recoup their revenue quickly (Taghizadeh-Hesary \& Yoshino, 2019). Hence, they ensure that the public facility is constructed within the stipulated period or even earlier. Scoring political points is also another motive for using the PPP concept to ensure the quick delivery of public facilities. Always, incumbent governments aim to develop infrastructure in the quickest possible time to gain political advantage over their opponent in the next general election.

According to Marco et al., (2017); Ngowi et al., (2006); and Owusu-Manu et al., (2019) the demand for infrastructure has outweighed its supply irrespective of recent political attention on the importance of infrastructure in modern years. It has become important for the government to seek additional funding for public projects. Aside from the huge funding gap, the Ghana Road Fund, Ghana Education Trust Fund (GETFund), and other infrastructure funds are in serious deficit. Resulting in local contractors often not paid on time. This has resulted in many abandoned public projects particularly roads and public schools (Amoatey et al., 2015; TwumasiAmpofo et al., 2014). Considering that PPP is the ideal option for the government to deliver the needed infrastructure in Ghana particularly in urban areas. 
PPP implementation in Ghana faces many obstacles as seen in many other developing countries (Chou \& Pramudawardhani, 2015). Nonetheless, the key challenges in Ghana's PPP practice include the lack of experience and appropriate skills in PPP delivery, misallocation, and incomplete transfer of risks (Osei-Kyei \& Chan, 2017; Owusu-Manu et al., 2019). Because of the complexities and large-scale nature of PPP projects, they require highly experienced personnel to handle and manage (Badu et al., 2011). Ghana has very little experience in managing PPP transactions. The majority of public officers and civil servants are more familiar with the traditional approach compared to PPP arrangements, and this has contributed largely to the slow pace of PPP development in Ghana (Badu et al., 2011; Owusu-Manu et al., 2019).

Given the poor environmental and socio-political conditions of PPP in Ghana, many risks affect the concept's success (Badu et al., 2011; Marco et al., 2017; Owusu-Manu et al., 2019). Moreover, it is also essential for practitioners to understand the possible allocations and sharing mechanisms for some key risks of PPP projects in Ghana. Osei-Kyei \& Chan, (2017) explored the critical risk factors of PPP projects and concluded that the key critical country-risk factors which need attention in Ghana include corruption, political/public opposition, exchange and interest rate fluctuations, poor public decision making, political interference, and project approvals and permit delays. On the other hand, some project-specific risks which are critical and also need consideration include construction cost overruns, delay in project completion, change in market demand, delay in land acquisition, high financing cost, construction changes, poor quality of workmanship, tariff change, environmental risk, and an experienced private partner (Alada \& Işik, 2018; Amoatey et al., 2015; Marco et al., 2017; Twumasi-Ampofo et al., 2014).

A review by Ameyaw and Chan, (2015) indicates that there is an inadequate legal framework for PPP practice in Ghana. Ghana has only a national policy guide; however, the guide does not give many details as to the implementation process. More essentially, the guide does not stipulate the procedures for managing unsolicited proposals, which are the widely adopted approach for PPP implementation by the government. PPP is an approach that the Ghanaian government has adopted to foster infrastructure development and meet the rapid urbanization growth in the country.

Notwithstanding, PPP is indeed feasible within the Ghanaian context despite the prevailing challenges; however, the concept needs proper restructuring before it can be successfully implemented (C. Ameyaw et al., 2015). The key issues that practitioners need to look at carefully to succeed include transparency and competition, favorable legal framework, right project identification, capacity building, extensive stakeholder engagement, and appropriate risk allocation (Osei-Kyei \& Chan, 2017). 


\section{THE NEXUS BETWEEN THE SDG AND THE PRIVATE SECTOR}

According to Van Noordwijk et al., (2018) the origination of the Millennium Development Goals, herald to the current SDGs brought the need for environmental sustainability and end of poverty in the highest-level of international conversation. The SDGs have enjoyed broad global acceptance and increasing business awareness (Muff et al., 2017). In a similar sense, Chirambo, (2018) emphasis that the SDGs have ruthless universal targets associated with increasing energy access, enhancing climate change mitigation and adaptation. In other to advance SDGs, success within each of these groups undoubtedly requires efforts that are at least compatible with goals in the other groups. According to the United Nations report (2018) cited by Kumi (2019), an underlying principle of achieving the SDGs is the recognition of the interdependency between social, economic, and environmental dimensions design to involve extensive multi-stakeholder collaboration between national governments, the international community, the private sector, Civil Society Organizations (CSOs) and academic institutions.

While the world acknowledges that persistent development, adoption of sustainable energies are critical towards the drive for sustainable development (AlQattan et al., 2018), a report from the United Nations' Conference on Trade and Development (UNCTAD) (2014) pointed out, policymakers believe that the annual investment gap for the SGDs will be provided by private sector actors. Furthermore, in developing countries, an annual investment estimate of US $\$ 4$ trillion is needed. Leaving a funding gap of US $\$ 2.5$ trillion per year (Dartey-Baah et al., 2015). The World Bank report Washington, DC: World Bank; (2016) cited by Hallegatte et al., (2016) also projected about US\$100 billion per year in investments in Africa will also be required to cope with its projected climate change impacts and over US\$600 billion to cover the costs for implementing the SDGs.

Mobilizing all the human and financial resources that are necessary to achieve these targets could be daunting, simply because traditional aid and public finance cannot cover the full costs for the SDGs implementation (Hutton \& Varughese, 2009) Again, there is an increasing acknowledgment in policy and public dialogue that the private sector can help deliver the SDGs even if not substantially with the sector's financial resources and innovation (Scheyvens et al., 2016; Van Zanten \& Van Tulder, 2018). In the research by Van Zanten and Van Tulder, (2018) they argue that the private sector been recognized as having the ability to reduce social inequalities through the development of inclusive and sustainable business approaches.

Liang \& Hu, (2020) suggest that Public-private partnership (PPP) offers an alternative means of involving the private sector in the delivery of public services. The reasoning behind the partnership is that of limited resources for the public sector, which will be needed to meet its numerous responsibilities. 


\section{CONCEPTUAL FRAMEWORK}

For this research Matji \& Ruiters, (2015) conceptual framework for PPP has been adopted in Figure 1. Matji \& Ruiters, (2015) define three main options for the PPPs. The framework identifies and categorizes important elements. These comprise on (i) component is $100 \%$ government-funded and owned infrastructure, (ii) at the other is 100\% private sector funded and retained infrastructure; and (iii) between government and the private sector is the hybrid model. Jomo et al., (2016) argues that the broader welfare benefits of projects should be paramount, including social externalities and the implications for sustainable development. The framework was developed through a qualitative approach by analyzing extant literature. This method is supported by Ruiters \& Matji, (2016) who argued that it allows researchers to use prevailing knowledge to develop theory. Grounded on this hypothesis, the understanding of the evolution of value for money (VfM) was traced from a purely economic viewpoint to its current knowledge and contextualized.

The advantage of this framework that makes it of superior interest for this research is its flexible applicability from the context of a specific sector. Interestingly, the framework raises vital inquiries that help in understanding the study problem and what potential solutions could be. Nevertheless, it was useful for this study. In this study, a broad challenge would be to frame PPP contractual guidelines in such a way that the PPPs would lead to VfM for the implementing parties and the public and not put undue constraints on governments and other stakeholders in support of the 2030 agenda for sustainable development (Ameyaw et al., 2015). To achieve the latent benefits of PPP, VfM assessment models, drivers, and approaches, challenges, and opportunities were identified and well synthesized. More recently, the framework has progressively been used in tackling problems in highly complex energy systems research. For example, Liu et al., (2013) proposed a dynamic life-cycle performance evaluation framework for PPP infrastructure projects, and Yuan et al., (2009) applied the goal-setting theory to construct a comprehensive evaluation framework for PPP.

Drawing from the foregoing discussion, for PPPs to succeed there have to be high levels of commitment from all stakeholders, and the process must be approached in a participatory and consultative manner to ensure that such partnerships are sustainable and beneficial towards promoting growth (Taghizadeh-Hesary \& Yoshino, 2019). The larger the PPP, the more important it is to have knowledgeable and well-capacitated partners, including governments who must play a principal role in project preparation, procurement, and post-closure performance monitoring. In the poorest countries, that kind of capacity does not exist, so donors try to create it, sometimes specifically for transformational projects (Leigland, 2018). Public sector accountability and little expectation towards long term success seek generally a short-term strategy, mainly because of political ties, which is fragile when compared with the return on investment approach demanded by the private sector. The latter generally has strong financial criteria and obligations and seeks to measure the success of projects as a business solution based 
on net present value and the rate of return on capital investment (Taghizadeh-Hesary \& Yoshino, 2019).

The good governance aspects of the partnership, as principles guiding the operation of the partnership and/or as its explicit objective, add a layer of complexity to partnership design and operation beyond the metrics of efficiency, effectiveness, and synergy. Acting on these principles means that inclusion, equity, transparency, accountability, and ethical behaviors become integral to partnership functions (Burlone, 2017; Johnston \& Gudergan, 2009). The forms of PPPs have been discussed by different authors and institutions based on context and the sector. The cross-cutting theme for adopting a PPP remains the purpose and the regulatory environment for the partnership. The implementation of the sustainable development goals is rife an opportunity to develop better and stronger partnerships with other state and non-state actors in the economy (Kynčlová et al., 2020). The main sources of funding for PPP projects are government grants, municipality's own revenue collected from users or equity, debt/loans raised on the strength of the municipality's balance sheet.

\section{FRAMEWORK FOR PUBLIC PRIVATE PARTNERSHIP}

\section{STATE MODEL}

- State funding is $100 \%$

- Infrastructure ownership by the state is $100 \%$

- The state carries the full cost of operation and maintenance in the infrastructure

- Private sector players are employed as consultant only

- No transfer of skills to Government officials

- Private sector retains skills to maximize revenue and financial sustainability

- Inefficiencies and prolong projects benefit private sector or consultants

- $\quad$ The state is both a referee and a payer

\section{HYBRID MODEL}

- $\quad$ Mixed funding between state and private sector

- Infrastructure ownership by the state

- Infrastructure maintenance outsourced

- $\quad$ There is knowledge and skills transfer by private sector to Government officials

- $\quad$ There is room for innovation and creativity

- State focuses on regulation of the private sector

- Operation and efficiency and cost optimization are achieved

- $\quad$ Project are completed on time and budget

\section{PRIVATE MODEL}

- $\quad$ Private sector funding is $100 \%$

- Infrastructure ownership is $100 \%$ private

- Private sector carries the full cost of the infrastructure maintenance

- State plays an effective regulator in the interest of consumers or users

- Private sector retains skills to maximize revenue, profit and future business

- Strategic social infrastructure such as water energy and sanitation are control by the private sector

Figure 1. A typical PPP framework. Source: (Matji \& Ruiters, 2015)

\section{METHODOLOGY}


The research adopted a qualitative method. The qualitative method was used to interpret the findings to enhance quality (Hallebone \& Priest, 2009). The population comprised of managers and technical staff of selected companies within the energy industry who have been part of PPP projects. This includes Power Distribution Services (PDS) Ghana, ENI Ghana, Kosmos Energy Ghana, Ministry of Energy (MoE), Energy Commission, Ministry of Finance (MoF), African Centre for Energy Policy (ACEP), and the Institute for Energy Security (IES) respectively. In the view of Campbell, (2002) the population of a study constitutes all the elements or units that bear characteristics, which are of interest to the researcher. The population size of the respondents was eighteen (18). According to Thyer and Grigsby (2019), there is no stern regulation on the number of respondents who should make up a purposive sample, so long as the information required is ascertained.

The sample size comprises stakeholders in the energy sector across the government, public, private sector and civil Society. Energy Commission, Ministry of Finance, National Development Planning Commission, Eni Ghana limited, Kosmos energy Ghana limited, PDS Ghana limited, African Center for Energy Policy, Arthur Energy Advisors, Civil Society platform on SDGs. The choice of the sample size was based on the discretion of the researcher backed by Dell et al., (2002). According to Dell et al. (2002), in choosing a sample size for a study, the researcher needs to choose a sample that he can have access to within the time frame in which the study is being conducted. Based on this premise, the researcher chose employees from these organizations.

The sampling technique used for the selection of the respondents was the purposive sampling technique. The purposive sampling technique was justified because the researcher needed to select respondents who have either been part of PPP project teams before or a currently engaged on PPP projects in their organizations as project team members or are members of their sustainability team if applicable.

Semi-structured interviews were used to collect data for the research. The semi-structured interview guides were grouped into three different sections. The first section comprised of the demographic data of the respondents such as their gender, age, educational level, and years of experience in the energy sector as shown in Table 1. The second section assesses their understanding of the SDGs and projects carried out by the organizations related to such. The third section assesses the opportunities and challenges that organizations encounter as they engage in PPP projects and what best practices exist to improve public-private partnerships.

An open-ended questionnaire was also used. The open-ended questions allowed respondents to express their opinion by way of comments. The questionnaires were distributed to respondents at a convenient time. The total number of interviews to be administered is eighteen (18).

Data gathered from the structured interviews was analyzed using descriptive statistics and identification of themes with data transcriptions. The descriptive statistic was used to analyze the 
demographic data of the respondents. Furthermore, thematic content analysis (TCA) was used to analyse the interview responses. Specific themes were identified based on each of the research objectives and then data transcriptions were used to explain and gain an in-depth understanding of the themes identified.

\section{Thematic Content Analysis (TCA)}

Thematic analysis as an independent qualitative descriptive approach is mainly described as "a method for identifying, analyzing, and reporting patterns (themes) within data" (Braun \& Clarke, 2006: 79). Thematic analysis can be conducted within both realist/essentialist and constructionist paradigms, although the outcome and focus will be different for each (Braun \& Clarke, 2006). TCA is a systematic coding and categorizing approach used for exploring large amounts of textual information unobtrusively to determine trends and patterns of words used, their frequency, their relationships, and the structures and discourses of (Kumi et al., 2020; Leech \& Onwuegbuzie, 2011; Sandelowski \& Leeman, 2012; Worthington et al., 2007).

The main feature of TCA is the orderly coding, examining of significance, and provision of a description and the creation of themes. The purpose of content analysis is to describe the characteristics of the document's content by examining who says what, to whom, and with what effect. In doing so the researcher first replicates a copy of the conversation transcript. This is followed by the identification of themes, with a focus on prominent elements in the texts (Vaismoradi et al., 2016). Third, related units were extracted and grouped (Sandelowski \& Leeman, 2012). Subsequently, the whole interview transcript is revised for appropriateness of all groupings, revised, and regrouped if necessary(Krippendorff, 2011). Lastly, to ensure that highquality findings are produced, this procedure is repeated up until all the extracted groupings reflect the interview transcripts as a whole Vaismoradi et al., (2016). Abubakari et al., (2013) and Simpson \& Buabeng, (2013) adopted TCA to investigate the implementation of public-private partnerships in Africa and the performance contract of public enterprises, respectively.

\section{DATA ANALYSIS AND DISCUSSION}

The findings of the research were obtained from the opinions of energy technocrats, CSOs, and policymakers through personal interviews and a secondary source of data. Purposive sampling technique was used to select the participants for the study. Due to the qualitative nature of the study thematic analysis was utilized. Demographic data of the respondents such as gender, age, educational level, and years of experience were presented through the use of descriptive statistics and presented in Table 1. Ten (10) interview responses were retrieved out of the eighteen (18) sent out to the energy companies, CSO, consultancy firms, ministries, and government agencies. This amounted to a response rate of 56 percent. This response rate attained is deemed adequate and high enough to proceed with the data analysis.

\section{Respondents' profile}


Table 1. Questionnaire response rate (Source: Author)

\begin{tabular}{|c|c|c|c|c|c|c|c|}
\hline \multicolumn{2}{|l|}{ Respondent } & Frequency & $\begin{array}{l}\text { Level of } \\
\text { Education }\end{array}$ & $\overline{\text { No }}$ & $\begin{array}{l}\text { Period of } \\
\text { work(years) }\end{array}$ & Frequency & $\%$ \\
\hline \multirow{4}{*}{ Organizations } & $\begin{array}{l}\text { Government } \\
\text { agency }\end{array}$ & 4 & \multirow{3}{*}{$\begin{array}{l}\text { First } \\
\text { Degree }\end{array}$} & \multirow[t]{3}{*}{0} & \multirow{2}{*}{ Below 5} & \multirow[t]{2}{*}{2} & 40.0 \\
\hline & $\begin{array}{l}\text { Civil society/ think } \\
\text { tank }\end{array}$ & 2 & & & & & 20.0 \\
\hline & $\begin{array}{ll}\begin{array}{l}\text { Energy } \\
\text { provider }\end{array} & \text { service } \\
\end{array}$ & 2 & & & \multirow[t]{2}{*}{$5-10$} & \multirow[t]{2}{*}{4} & 20.0 \\
\hline & Energy consultancy & 2 & \multirow{3}{*}{$\begin{array}{l}\text { Master's } \\
\text { degree }\end{array}$} & \multirow[t]{3}{*}{6} & & & 20.0 \\
\hline \multirow{5}{*}{ Positions } & $\begin{array}{l}\text { Director } \\
\text { Planning }\end{array}$ & 2 & & & $11-15$ & 2 & 20.0 \\
\hline & $\begin{array}{l}\text { Local content } \\
\text { coordinator }\end{array}$ & 2 & & & $16-20$ & 0 & 20.0 \\
\hline & $\begin{array}{l}\text { Sustainability } \\
\text { manager }\end{array}$ & 4 & \multirow[t]{2}{*}{$\mathrm{PhD}$} & \multirow[t]{2}{*}{4} & & & 40.0 \\
\hline & Policy analyst & 2 & & & above 20 & 0 & 20.0 \\
\hline & Total & 20 & & 10 & & 8 & \\
\hline
\end{tabular}

It was found that males participated in the study more than females, as they constituted $60 \%$, Females constituted $40 \%$ of the remaining respondents. In terms of the experience distribution, it was found that the majority of the respondents comprising 60\% had between 5-10 years of experience in their positions, $20 \%$ had more than 10 years of experience in their position while the remaining $20 \%$ had between 0-5 years of experience. With regards to the educational level of respondents, it was found that the majority of them had attained their Master's degree (60\%) while $40 \%$ had attained their Ph.D. Per the working experiences and educational level of the respondents, it could be deduced that respondents are very eligible for this study because they have the requisite knowledge and experience in either the energy sector, PPPs, Sustainable development or both.

\section{Challenges of mainstreaming the SDGs in Ghana's energy sector}

The lack of a government policy document on PPP implementation in Ghana causes government institutions to enter into partnerships with the private sector without any reference document. Conflict of interest in the implementation of PPPs is identified as a major gab. Addressing these challenges legally becomes cumbersome when initiating contracts or during disputes resolution. Some participants further noted that in several instances the private sector actors will consider the economic stability in the country before investing in PPPs. This reduces the risk profile of the investment. Issues of accountability and excessive government control on PPP projects was identified as a major impeding factor in the energy sector.

Most participants have varied but a common understanding of the SDGs. Respondents from the public sector particularly had a deeper understanding and comprehensive definition of the SDGs compared to the private sector. The experts from the National Development Planning 
Commission (NDPC) on the public sector side for example, which is the seat of Ghana's SDG implementation gave the most comprehensive understanding of the SDGs. Interviewees discuss their understanding on SDGs as follows;

"At NDPC, our understanding of the SDGs is that they are a set of 17 goals that were identified through a participatory process, based on critical issues facing the earth and humanity, both developed and developing, with a call to all countries to take actions towards addressing these critical issues based on circumstances and capabilities to make the world a better place”.

"The Energy commission understands the SDGs as developing the well-being of the present generation without hurting the ability of future generations to develop."

"At ACEP, we understand UN SDGs as a set of global goals or agenda for development; leveraging on member countries, leaving no one behind."

"ENI oil sees the SDGs as global goals drafted and accepted by all UN member countries as the new framework for development replacing the Millennium Development Goals but this time around with a broader perspective on the environment, economy and social development."

"AEA defines the sustainable development goals as a set of global ambitions to address developmental challenges across the various phases of human existence from the economic issues to social issues than environmental by bringing together all actors from business to government to civil society to achieve these common goals."

\section{Opportunities for mainstreaming the SDGs in Ghana's energy sector}

Most participants mentioned a partnership between the government and private sector will enhance efficiency, technology transfer and mobilizing additional financing for development. They highlight that PPPs could help the private sector to maximize business opportunities and profits by creating a niche for themselves and also create new business entry points. Similar opinions have also been expressed by a respondent from the Energy Commission as follows; "private sector brings efficiency, technology transfer and financial resources which is a good opportunity for government".

The research results demonstrate that most of business interventions have not been labelled as SDG but implemented under the umbrella of CSR, community investment strategies or other purposes. In terms of SDG related interventions the respondents from ENI mentioned the company's partnership with the Bui Power Authority and the UNDP under a tripartite arrangement to implement a $50 \mathrm{MW}$ solar renewable energy project related to the SDG 7 (Affordable clean energy) and another partnership with the Forestry Commission to implement an afforestation project to reduce the company's carbon footprint related to SDG 13 (Climate Action) and SDG I5 (Life on land). So far, the ENI example comes across as an ideal case study in the energy industry of Ghana. 
Some participants from the Energy Commission mentioned the ENI/GoG Onshore Receiving Facility (ORF) built for onshore power production; as a 'game-changer' in terms of improving access to energy which invariably aligns with the SDGs. This will lead to a cheaper energy that will spur economic development and reduce poverty. Others from AEA also mentioned the case of Safi Sana Ghana's waste to energy facility in Ashaiman as a good example of an integrated business model where municipal waste collected is converted to energy for the grid and also for the production of fertilizer that contributes to the SDG on 'No Hunger'.

Several respondents referred to Tullow Oil and Kosmos Energy community water projects that contribute to achieving SDG 6 on clean water and sanitation. Aker Energy and GNPC educational scholarship scheme that contributes to SDG Goal 4 on quality education, as examples of business activities even though they are not SDG labeled, the reason being that some of these interventions were started before the SDGs were adopted by the UN.

In response to the policy and regulation, there was a divergence in opinion as to the measures that could be adopted through policy to ensure that the right environment is created for PPP takeoff and suitability. Majority of participants agreed that except for the local content regulation for the oil and gas sector which seeks to regulate the mandatory participation of locals in the sector, the policy gap in very prominent. They cited the lack of a clear policy direction on PPP that leaves energy companies with no choice but to resort to international rules and standards set up by organizations such as the International monetary fund (IMF) and the International chamber of commerce (ICC). To address this void respondent suggested the introduction of policy instruments and incentives such as tax holidays, tax waivers, tax rebates, subsidies, and mandatory SDG related and local content clauses. Others noted that the policy environment will be able to dictate the right incentives, regulations, and targets that fit the Ghanaian context with limited compromises. A respondent from ACEP said;

"Energy companies are left with no choice since there is no clear policy or regulation on PPPS but resort to international best practice"

"Government has to encourage private sector participation by providing incentives such as tax rebates, tax waivers, tax holidays, tax breaks, concessions, and subsidies" Respondent from NDPC

"The kind of PPP policy Ghana needs should be made to fit the local context but internationally appealing so that the interest of the country is assured whiles attracting the needed resources for development". A respondent from AEA.

\section{Strategies for mainstreaming the SDGs Ghana's energy sector}

The experts from ENI shared a view that as part of their internal policies before any project is executed, they undertake environmental, social, and health impact assessment (ESHIA) of their projects to ensure that apart from making economic gains they are also addressing the social and environmental concerns in their operational area. From a policy perspective, respondents from 
the NDPC highlighted how some the triple bottom line can be achieved when linked with the holistic picture of business development interventions. For example, workforce and customer training for environmental compliance. A few of them that environment, economy, and society should be intrinsically linked such that there is no imbalance. Such awareness creation could be better, implemented and measured with an index rather than using only economic indicators to measure development. An expert from ENI put its as follows;

"At ENI before we undertake our projects, we conduct an environmental, social and health impact assessment (ESHIA) to ensure that we are addressing all concerns associated with the project to protect our investment and also ensure we are providing value to our host community through our CSR and community investment strategy (CIS)."

"to promote sustainability there has to be a shift from always measuring economic indicators which fuels the profit mindset and begin to measure other things like inclusivity" Respondent from ACEP

Several respondents gave varying but consistent approaches to mainstreaming the SDGs. Some were of the view that mainstreaming should not be by compulsion but by constant awareness creation within the energy sector. Using beneficial motives such as the savings on the cost of energy by using energy-efficient equipment and others. Through this approach companies will adopt measures best fit for their context. Others also indicated that organizations in the energy industry must begin to develop new business models that respond to the needs and vulnerabilities of people around them. For instance, to recruit more persons with physical disabilities either as employees or including businesses owned by persons with disabilities in their local supply chain. This will create an inclusive index and could be a good measure for energy companies.

Furthermore, respondents from the public sector noted the key role the policy environment could play by aligning national policies to ensure issues of emissions, gender, health, etc. are brought to the front-burner and encourage uptake of renewable energy technologies in the energy mix. Few of the suggestions given by the experts include (i) carbon and emissions trading to be explored by businesses as a way of cutting down their environmental footprint. (ii) a wellestablished sustainability unit in the organization with the mandate and resources to design strategies for the company to improve environmental and social performance. (iii) CSR policies should be aligned with the SDG targets to help track their contributions. The important of forming partnerships with organizations such as the UNDP and other institutions to implement projects targeting specific SDG goal was also suggested.

"Companies should be made to understand the benefits of taking up initiatives such as energy efficiency which will reduce their cost of doing business and redirecting savings into business expansion". Respondents from NDPC

"Companies must begin to revise their business models to cater for the less privileged and the vulnerable by employing such persons and also giving out contracts to businesses owned by such people”. Respondents from AEA. 
"Government should begin to align national policies with the SDGs to ensure that issues on emissions, gender and health are prioritized by energy companies in this case". Respondents from Energy commission.

\section{FINDINGS, CONTRIBUTION, AND IMPLICATIONS}

Research results have indicated that the implementation of PPP should be guided by a consistent policy, the legal regime from the government to ensure that public interest is protected, and private sector returns guaranteed. Ameyaw \& Chan, (2015) confirm that there is an inadequate legal framework for PPP practice in Ghana that supported this finding. Ghana has only a national policy guide. The research agreed with Chu (1999); Painuly, (2009); Twumasi-Ampofo et al., (2014) that for PPP to succeed there has to be high levels of commitment from all stakeholders, and the process must be approached in a participatory and consultative manner to ensure that such partnerships are sustainable and beneficial towards promoting growth.

The study recognized incentives to the private sector as one of the best practices to attract private sector investments in PPP as confirmed by (Leigland, 2018). On the issue of mainstreaming the SDGs respondents suggested that social and environmental safeguards should be enshrined in the design of PPP projects and policy to ensure no one is left behind. Jomo et al., (2016) support the assertion by respondents that the PPP introduction will bring efficiency and inclusive growth. According to Jomo et al., (2016), the prime objective of a PPP is an improvement in the quality and efficiency of a given service to the citizen. Regarding best practices, the respondents claim to ensure equal partnership as is the case with the ENI 'Dual flag' approach.

In this analysis, for PPP to have its full effect in Ghana there has to be a proper and effective regulatory environment to ensure that the concerns of both the private sector and government are addressed when drafting and choosing PPP contracts. As confirmed by Simshauser et al., (2016) some of the critical best practices include transparency and competition, favorable legal framework, right project identification, capacity building, extensive stakeholder engagement, and appropriate risk allocation.

The study also discovered that for a PPP to be more effective it has to approached from consensus and equal partnership position. As indicated in the ENI 'Dual Flag' approach this ensures that both the government and the private sector are engaging on equal terms without any acrimony or suspicion but rather working together to achieve a common goal within a transparent and mutually respectful atmosphere.

The study identified the lack of a clear and consistent policy on PPPs in Ghana. This leads to issues of conflict of interest, excessive government control, and manipulation of PPP projects with little respect for contracts. This challenge is further complicated by the lack of an appropriate legal framework for dispute resolution and a cumbersome licensing regime. These challenges make PPPs unattractive to businesses or the private sector who will want to see consistency, transparency, and profitability before investing their resources. Again, the 
research found that apart from the financial rewards emanating from PPP projects to the private sector government was also relieved of its financial burden and responsibilities giving it the room to spend on other key sectors of the economy. The efficiency, technology, and expertise of the private sector also ensure that the quality of PPP projects is second to none. The private sector also benefits by creating a niche for themselves and discover new business entry points which add to their brand reputation.

For some companies, the approach for mainstreaming should be constant awareness creation and education on the potential benefits of adopting sustainability principles. It would be necessary for companies to develop new business models that cater for sustainability by including all stakeholders along the value chain and redefining its business engagements to include SMEs, vulnerable groups, and persons with disabilities for example. One effective way of mainstreaming the SDGs from the research is emissions trading by energy companies to ensure that their operations produce a zero-carbon footprint. Businesses needed to form partnerships with institutions with relevant knowledge, expertise, and mandate in the implementation of the SDGs such as the UN and its subsidiary bodies to ensure credibility, sustainable impact, and replication in other areas by documenting and reporting on the process.

The majority of companies in the energy sector are implementing various interventions that address one social, economic, or environmental problem in the host communities. These interventions span from waste to energy projects by Safi Sana addressing sanitation problems, creating jobs, and supplying energy to the national grid. The findings also show that Tullow Oil and Kosmos energy have constructed community water supply systems for deprived areas around the country to provide access to clean drinking water, reduce waterborne diseases, and promoting economic development. Some companies like GNPC and AKER energy are providing educational scholarships to ensure brilliant but needy children have access to quality education, equipped with the capacity to contribute to national development. The study also found that ENI has also partnered with the Bui Power Authority to implement a solar energy project within the catchment area of the Bui dam. The study deduced that even though there are a good number of SDG related projects being implemented by some energy companies, the communication and labeling of such projects have been under their corporate social responsibility (CSR) agenda and not as SDG interventions.

\section{CONCLUSION AND RECOMMENDATIONS}

The research concluded that governments have to put in place a PPP policy and regulation to guide the practice of PPPs in Ghana. The policy should spell out the various governance structures, processes, institutions, roles and responsibilities, incentives, qualifications, and target areas with sustainability goals embedded which can be known as the sustainable PPP model. National targets should feature in relevant policy documents to ensure a holistic implementation of the SDGs across all levels of government sectors from ministries, departments, and agencies 
(MDAs) to metropolitan, municipal and district assemblies (MMDAs). This will ensure the SDGs impacts the lives of the ordinary Ghanaian.

Again, the study advocate for the government to intensify its engagement with the private sector to create the needed awareness, educating and making the business case to attract private sector interest and provide incentives. The private sector should be made aware of how the SDGs benefit their business, protects its supply chain, promotes the wellbeing of their employees, and ensure guaranteed raw material base. Private sector participants in the implementation of the SDGs should be encouraged to report on their SDG related actions and activities to enable government and other stakeholders to monitor, measure, verify, and commend such companies.

This will enable the government to quantify the contribution of various stakeholders in the implementation of SDGs.

The study agree with literature (Kwofie et al., 2019) that, to establish the role of public-private partnerships in the implementation of the SDGs. The study recommends the scope of this study to be extended to other industries such as the mining and quarrying sector among others in the energy value chain. Research results have indicated that, with the exception of the local content regulation for the oil and gas sector which seeks to regulate the mandatory participation of locals, there is still an existence of prominent policy gaps. Also, the lack of a clear policy decision on PPP leaves energy companies with no choice but resort to international rules and standards within the International monetary fund (IMF) and the International Chamber of Commerce (ICC). To address these challenges, the paper suggests that;

- The policy environment should be made internationally responsive and locally relevant through government commitment and political will to attract business action.

- An introduction of policy instruments and incentives such as tax holidays, tax waivers, tax rebates, subsidies and mandatory SDG related and local content clauses.

- Cost auditing by the host government to ensure that the private partners declares the right amount of expenditure on goods and services. This will avoid transfer pricing and the resultant reduction in tax obligations during SDG project execution.

- The legal regime for commercial dispute resolution should be streamlined. This could be done with the principles and rules of the International Centre for Settlement of Investment Disputes (ICSID) and the International Court of Arbitration (ICA). This will strengthen the confidence in the private sector in the SDG business environment for PPP.

\section{REFERENCES}

Abubakari, Maliha, Buabeng, T., \& Ahenkan, A. (2013). Implementing Public Private Partnerships in Africa:The Case of Urban Water Service Delivery in Ghana. Journal of Public Administration and Governance, 3(1), 41-56. https://doi.org/10.5296/jpag.v3i1.3252 
Abubakari, Mohammed, Asamoah, P. K. B., \& Agyemang, F. O. (2018). Ghana and Sustainable Development: The 40-Year National Development Plan in Retrospective. Journal of Human Resource and Sustainability Studies, 6(1), 24-36. https://doi.org/10.4236/jhrss.2018.61024

Acheampong, M., Yu, Q., Ertem, F. C., Ebude, L. D. E., Tanim, S., Eduful, M., Vaziri, M., \& Ananga, E. (2019). Is Ghana ready to attain sustainable development goal (SDG) number 7?-A comprehensive assessment of its renewable energy potential and pitfalls. Energies, 12(3), 408. https://doi.org/10.3390/en12030408

Acuti, D., Bellucci, M., \& Manetti, G. (2020). Company disclosures concerning the resilience of cities from the Sustainable Development Goals ( SDGs ) perspective. Cities, 99, 102608. https://doi.org/10.1016/j.cities.2020.102608

Agarchand, N., \& Laishram, B. (2017). Sustainable Infrastructure Development Challenges through PPP Procurement Process : Indian Perspective. International Journal of Managing Projects in Business, 10(3), 642-662. https://doi.org/10.1108/IJMPB-10-2016-0078

Alada, H., \& Işik, Z. (2018). The Effect of Stakeholder-Associated Risks in Mega-Engineering Projects: A Case Study of a PPP Airport Project. IEEE Transactions on Engineering Management, 6(1), 174-186. https://doi.org/10.1109/TEM.2018.2866269.

AlQattan, N., Acheampong, M., Jaward, F. M., Ertem, F. C., Vijayakumar, N., \& Bello, T. (2018). Reviewing the potential of Waste-to-Energy (WTE) technologies for Sustainable Development Goal (SDG) numbers seven and eleven. Renewable Energy Focus, 27, 97110. https://doi.org/10.1016/j.ref.2018.09.005

Ameyaw, C., Adjei-Kumi, T., \& Owusu-Manu, D. G. (2015). Exploring value for money (VfM) assessment methods of public-private partnership projects in Ghana: A theoretical framework. Journal of Financial Management of Property and Construction, 20(3), 268285. https://doi.org/10.1108/JFMPC-01-2015-0003

Ameyaw, E. E., \& Chan, A. P. C. (2015). Evaluation and ranking of risk factors in public-private partnership water supply projects in developing countries using fuzzy synthetic evaluation approach. Expert Systems with Applications, 42(12), 5102-5116. https://doi.org/10.1016/j.eswa.2015.02.041

Amoatey, C. T., Ameyaw, Y. A., Adaku, E., \& Famiyeh, S. (2015). Analysing delay causes and effects in Ghanaian state housing construction projects. International Journal of Managing Projects in Business, 8(1), 198-214. https://doi.org/10.1108/IJMPB-04-2014-0035

Arhin, A. (2016). Advancing post-2015 Sustainable Development Goals in a changing development landscape: Challenges of NGOs in Ghana. Development in Practice, 25(5), 555-568. https://doi.org/10.1080/09614524.2016.1189513

Badu, E., Owusu-Manu, D.-G., Edwards, D. J., \& Holt, G. D. (2011). Innovative financing (IF) of infrastructure projects in Ghana: conceptual and empirical observations. Engineering Project Organization Journal, $\quad$ 1(4), 255-268. https://doi.org/10.1080/21573727.2011.597744 
Badu, E., Owusu-Manu, D.-G., Edwards, D. J., \& Holt, G. D. (2013). Analysis of Strategic Issues Underpinning the Innovative Financing of Infrastructure within Developing Countries. Journal of Construction Engineering and Management, 6(139), 1-13. https://doi.org/10.1061/(ASCE)CO.1943-7862

Benshaul-Tolonen, A., Chuhan-Pole, P., Dabalen, A., Kotsadam, A., \& Sanoh, A. (2019). The local socioeconomic effects of gold mining: Evidence from Ghana. Extractive Industries and Society, 6(4), 1234-1255. https://doi.org/10.1016/j.exis.2019.07.008

Burlone, N. (2017). Public-Private Partnerships: When Ethics and Policy Making are an Afterthought. Revue Gouvernance, 3(2). https://doi.org/10.7202/1039119ar

Campbell, J. (2002). A critical appraisal of participatory methods in development research. International Journal of Social Research Methodology. https://doi.org/10.1080/13645570110098046

Castor, J., Bacha, K., \& Nerini, F. F. (2020). Energy Research \& Social Science SDGs in action : A novel framework for assessing energy projects against the sustainable development goals. Energy Research \& Social Science, 68, 101556. https://doi.org/10.1016/j.erss.2020.101556

Chirambo, D. (2018). Towards the achievement of SDG 7 in sub-Saharan Africa: Creating synergies between Power Africa, Sustainable Energy for All and climate finance in-order to achieve universal energy access before 2030. Renewable and Sustainable Energy Reviews, 94, 600-608. https://doi.org/10.1016/j.rser.2018.06.025

Chou, J. S., \& Pramudawardhani, D. (2015). Cross-country comparisons of key drivers, critical success factors and risk allocation for public-private partnership projects. International Journal of Project Management, 33(5), 1136-1150. https://doi.org/10.1016/j.ijproman.2014.12.003

Chu, J. (1999). The BOOT approach to energy infrastructure management: a means to optimise the return from facilities. Facilities, 17(12/13), 492-498. https://doi.org/10.1108/02632779910293497

Dartey-Baah, K., Amponsah-Tawiah, K., \& Agbeibor, V. (2015). Corporate social responsibility in Ghana's national development. Africa Today, 62(2), 71-92. https://doi.org/10.2979/africatoday.62.2.71

Dell, R. B., Holleran, S., \& Ramakrishnan, R. (2002). Sample Size Determination. ILAR Journal, 26(1), 70. https://doi.org/10.1093/ilar.43.4.207

Hallebone, E., \& Priest, J. (2009). Business and Management Research. In Business and Management Research. https://doi.org/10.1007/978-1-137-11078-7

Hallegatte, S., Bangalore, M., Bonzanigo, L., Fay, M., Kane, T., Narloch, U., Rozenberg, J., Treguer, D., \& Vogt-Schilb, A. (2016). SHOCK WAVES Climate Change and Development Series Managing the Impacts of Climate Change on Poverty. World Bank Group. https://doi.org/10.1596/978-1-4648-0673-5

Han, J., Jia, M., Wu, G., \& Yang, H. (2020). Strategic Interaction Between the Government and 
the Private Sector in PPP Projects Incorporating the Fairness Preference. IEEE Access, 8, 37621-37631. https://doi.org/10.1109/ACCESS.2020.2975821

Hutton, G., \& Varughese, M. (2009). The Costs of Meeting the 2030 Sustainable Development Goal Targets on Drinking Water, Sanitation, and Hygiene: Summary Report. The Costs of Meeting the 2030 Sustainable Development Goal Targets on Drinking Water, Sanitation, and Hygiene: Summary Report, 3(3), 293-207. https://doi.org/10.1596/k8632

Jingning, Y., \& Wenkang, L. (2016). Risk Assessment Model of Urban Subway Based on Public Private Partnership Mode. Proceedings - 2015 6th International Conference on Intelligent Systems Design and Engineering Applications, ISDEA 2015, 700-703. https://doi.org/10.1109/ISDEA.2015.179

Johnston, J., \& Gudergan, S. (2009). Ethical leadership in public-private partnerships: Learning from an Australian "great controversy"? In Public Sector Leadership: International Challenges and Perspectives (pp. 276-293). https://doi.org/10.4337/9781848449343.00026

Jomo, K., Chowdhury, A., Sharma, K., \& Platz, D. (2016). Public-Private Partnerships and the 2030 Agenda for Sustainable Development: Fit for purpose? In DESA Working Paper.

Krippendorff, K. (2011). Agreement and information in the reliability of coding. Communication Methods and Measures, 5(2), 93-112. https://doi.org/10.1080/19312458.2011.568376

Kumi, E. (2019). Advancing the Sustainable Development Goals: An Analysis of the Potential Role of Philanthropy in Ghana. Journal of Asian and African Studies, 54(7), 1084-1104. https://doi.org/10.1177/0021909619862591

Kumi, E., Yeboah, T., \& Kumi, Y. A. (2020). Private sector participation in advancing the Sustainable Development Goals (SDGs) in Ghana: Experiences from the mining and telecommunications sectors. Extractive Industries and Society, 1, 1-5. https://doi.org/10.1016/j.exis.2019.12.008

Kwofie, T. E., Afram, S., \& Botchway, E. (2016). A critical success model for PPP public housing delivery in Ghana. Built Environment Project and Asset Management, 6(1). https://doi.org/10.1108/BEPAM-04-2014-0026

Kwofie, T. E., Ohis Aigbavboa, C., \& Thwala, W. D. (2019). Communication performance challenges in PPP projects: cases of Ghana and South Africa. Built Environment Project and Asset Management, 9(5), 628-641. https://doi.org/10.1108/BEPAM-11-2018-0137

Kynčlová, P., Upadhyaya, S., \& Nice, T. (2020). Composite index as a measure on achieving Sustainable Development Goal 9 (SDG-9) industry-related targets: The SDG-9 index. Applied Energy, 265, 114755. https://doi.org/10.1016/j.apenergy.2020.114755

Leech, N. L., \& Onwuegbuzie, A. J. (2011). Beyond Constant Comparison Qualitative Data Analysis: Using NVivo. School Psychology Quarterly, 26(1), 71. https://doi.org/10.1037/a0022711

Leigland, J. (2018). Public-private partnerships in developing countries: The emerging evidencebased critique. World Bank Research Observer, 33(1), 103-104. 
https://doi.org/10.1093/wbro/lkx008

Liang, Q., \& Hu, H. (2020). Study on Identification of Spurious Public-Private Partnership Projects in China. IEEE Transactions on Engineering Management, 67(2), 376-384. https://doi.org/10.1109/TEM.2018.2877261

Liu, J., Love, P. E. D., Davis, P. R., Smith, J., \& Regan, M. (2013). Conceptual framework for the performance measurement of public-private partnerships. Journal of Infrastructure Systems, 55-64. https://doi.org/10.1061/(ASCE)IS.1943-555X.0000210

Marco, A. De, Mangano, G., Marco, A. De, \& Mangano, G. (2017). Risk factors in fl uencing the debt leverage of project fi nancing initiatives in the energy industry. International Journal of Energy Sector Management, 11(3), 444-462. https://doi.org/10.1108/IJESM-022017-0006

Matji, M. P., \& Ruiters, C. (2015a). Conceptual Framework for Public-Private Partnerships Model for Water Services Infrastructure Assets: Case Studies from Municipalities in the Limpopo and Gauteng Provinces. In Proceeding of the AMPEAK Asset Management Conference, May, 24-27.

Matji, M. P., \& Ruiters, C. (2015b). Conceptual Framework for Public-Private Partnerships Model for Water Services Infrastructure Assets: Case Studies from Municipalities in the Limpopo and Gauteng Provinces. AMPEAK Asset Management Conference, 24-27.

Muff, K., Kapalka, A., \& Dyllick, T. (2017). The Gap Frame - Translating the SDGs into relevant national grand challenges for strategic business opportunities. International Journal of Management Education, 363-383. https://doi.org/10.1016/j.ijme.2017.03.004

Ngowi, A. B., Pienaar, E., Akindele, O., \& Iwisi, D. S. (2006). Globalisation of the construction industry: A review of infrastructure financing. Journal of Financial Management of Property and Construction, 11(1), 45-58. https://doi.org/10.1108/13664380680001079

Opoku, M. P., J-F, Swabey, K., Pullen, D., \& Dowden, T. (2019). Poverty alleviation among persons with disabilities via United Nations' sustainable development goals in Ghana: Voices of stakeholders with disabilities. Sustainable Development, 27(1), 175-182. https://doi.org/10.1002/sd.1899

Osei-Kyei, R., \& Chan, A. P. . (2017). Implementation constraints in public-private partnership Empirical comparison between developing and developed economies/countries. Journal of Facilities Management, 15(1), 90-106.

Owusu-Manu, D. G., Edwards, D. J., Kutin-Mensah, E. K., Kilby, A., Parn, E., \& Love, P. E. (2017). The impact of socio-political and economic environments on private sector participation in energy infrastructure delivery in Ghana. Journal of Engineering, Design and Technology, 15(2), 166-180. https://doi.org/10.1108/JEDT-02-2016-0007

Owusu-Manu, D. G., Jehuri, A. B., Edwards, D. J., Boateng, F., \& Asumadu, G. (2019). The impact of infrastructure development on economic growth in sub-Saharan Africa with 
special focus on Ghana. Journal of Financial Management of Property and Construction, 24(3), 253-273. https://doi.org/10.1108/JFMPC-09-2018-0050

Owusu-Manu, D. G., Kukah, A. S., Edwards, D. J., Pärn, E. A., El-Gohary, H., Aigbavboa, C., \& El-Gohary, H. (2018). Causal relationships of moral hazard and adverse selection of Ghanaian Public-Private-Partnership (PPP) construction projects. Journal of Engineering, Design and Technology, 16(3). https://doi.org/10.1108/JEDT-12-2017-0137

Painuly, J. P. (2009). Financing energy efficiency: Lessons from experiences in India and China. International Journal of Energy Sector Management, 3(3), 293-307. https://doi.org/10.1108/17506220910986815

Pedersen, C. S. (2018). The un Sustainable Development Goals (SDGs) are a Great Gift to Business! Procedia CIRP, 69. https://doi.org/10.1016/j.procir.2018.01.003

Ruiters, C., \& Matji, M. P. (2016). Public-private partnership conceptual framework and models for the funding and financing of water services infrastructure in municipalities from selected provinces in South Africa. Water SA, 42(2), 291-305. https://doi.org/10.4314/wsa.v42i2.13

Sánchez, M., Ochoa M, W. S., Toledo, E., \& Ordóñez, J. (2020). The relevance of Index of Sustainable Economic Wellbeing. Case study of Ecuador. Environmental and Sustainability Indicators, 6(May), 100037. https://doi.org/10.1016/j.indic.2020.100037

Sandelowski, M., \& Leeman, J. (2012). Writing usable qualitative health research findings. Qualitative Health Research, 22(12), 1404-1413. https://doi.org/10.1177/1049732312450368

Scheyvens, R., Banks, G., \& Hughes, E. (2016). The Private Sector and the SDGs: The Need to Move Beyond 'Business as Usual.' Sustainable Development, 24(6), 371-382. https://doi.org/10.1002/sd.1623

Simpson, S. N. Y., \& Buabeng, D. T. (2013). Performance Contract and Performance of Public Enterprises: A Study of the Implementation Processes. Journal of Public Administration and Governance, 3(2), 10-21. https://doi.org/10.5296/jpag.v3i2.3792

Simshauser, P., Smith, L., Whish-Wilson, P., \& Nelson, T. (2016). Foreign aid via 3-Party Covenant Financings of capital-intensive infrastructure. Journal of Financial Economic Policy, 8(2), 183-211. https://doi.org/10.1108/JFEP-11-2015-0067

Taghizadeh-Hesary, F., \& Yoshino, N. (2019). The way to induce private participation in green finance and investment. Finance Research Letters, 31, 98-103. https://doi.org/10.1016/j.frl.2019.04.016

The World Bank. (2017). PPP Disclosure Diagnostic Report and Web-based Portal Launched Ministry of Finance | Ghana. https://mofep.gov.gh/news/2018-01-31/ppp-disclosurediagnostic-report-and-web-based-portal-launched

Thyer, B. A., \& Grigsby, R. K. (2019). Participant Observation Studies. In The Handbook of Social Work Research Methods. https://doi.org/10.4135/9781544364902.n23 
Twumasi-Ampofo, K., Osei, E., Decardi-nelson, I., \& Ofori, P. A. (2014). A Model for Reactivating Abandoned Public Housing Projects in Ghana. Civil and Environmental Research and Building and Road Research Institute, 6(3), 6-16.

UNCTAD. (2014). World Investment Report 2014: Investing in the SDGs. World Investment Report. https://doi.org/978-92-1-112873-4

Vaismoradi, M., Jones, J., Turunen, H., \& Snelgrove, S. (2016). Theme development in qualitative content analysis and thematic analysis. Journal of Nursing Education and Practice. https://doi.org/10.5430/jnep.v6n5p100

van Noordwijk, M., Duguma, L. A., Dewi, S., Leimona, B., Catacutan, D. C., Lusiana, B., Öborn, I., Hairiah, K., \& Minang, P. A. (2018). SDG synergy between agriculture and forestry in the food, energy, water and income nexus: reinventing agroforestry? In Current Opinion in Environmental Sustainability. https://doi.org/10.1016/j.cosust.2018.09.003

van Zanten, J. A., \& van Tulder, R. (2018). Multinational enterprises and the Sustainable Development Goals: An institutional approach to corporate engagement. Journal of International Business Policy, 1(3-4), 208-233. https://doi.org/10.1057/s42214-018-0008-x

Worthington, R. L., Soth-McNett, A. M., \& Moreno, M. V. (2007). Multicultural Counseling Competencies Research: A 20-Year Content Analysis. Journal of Counseling Psychology, 54(4), 351. https://doi.org/10.1037/0022-0167.54.4.351

Yakovleva, N., Kotilainen, J., \& Toivakka, M. (2017). Reflections on the opportunities for mining companies to contribute to the United Nations Sustainable Development Goals in sub - Saharan Africa. In Extractive Industries and Society. https://doi.org/10.1016/j.exis.2017.06.010

Yuan, J., Zeng, A. Y., Skibniewski, M. J., \& Li, Q. (2009). Selection of performance objectives and key performance indicators in public-private partnership projects to achieve value for money. Construction Management and Economics, 27(3), 253-270. https://doi.org/10.1080/01446190902748705 